\title{
The Thematic and Aesthetic Qualities of ISIS media production
}

\author{
Afif J. Arabi \\ Lebanese International University \\ Afif.arabi@liu.edu.lb
}

\begin{abstract}
This paper is set out to investigate the thematic and aesthetic qualities and the production process of ISIS film productions and to explore several issues arising from ISIS new trend in image production in areas of conflict. Scripted, rehearsed, performed and staged, these images can be read as "sociograms" where the director, cinematographer, subject/victim and apparatus collide to produce a Durkheimian "collective representation".
\end{abstract}

Keywords: Terrorism, ISIS, al-Qaeda, Media Production, Aesthetics, Collective representation.

\section{INTRODUCTION}

In the eighties, al-Qaeda produced promotional and propaganda videos using VHS and Betamax consumer analogue technology showing "heroic" real action from the battlefields against the Russians in Afghanistan. These productions were disseminated through physical pass-on process in the form of low picture quality dubbed video tapes. Similar practice was also the case of al-Qaeda operations against American troops in Iraq in the aftermath of the U.S. invasion of Iraq in 2003 but with access to posting such videotaped real events/operations on-line. The advancement in digital cinematography, videography, social media, internet speed and the high quality-low cost digital production equipment gave rise to a new breed of promotional and propaganda production at the hands of the al-Qaeda offshoot, the Islamic State of Iraq and Syria (ISIS). Botz-Bornstein (2017, p.6) suggested that "ISIS aesthetics represents a clear break with earlier Jihadi propaganda ... Al-Qaeda videos look extremely amateurish in comparison." In its war in Iraq and Syria, ISIS has produced sophisticated content technically, thematically and aesthetically which surpassed its predecessors.

My paper is set out to investigate the thematic and aesthetic qualities and the production process of ISIS film productions and to explore several issues arising from ISIS new trend in image production in areas of conflict. Scripted, rehearsed, performed and staged, these images can be read as "sociograms" where the director, cinematographer, subject/victim and apparatus collide to produce a Durkheimian "collective representation".

\section{BACKGROUND:}

During the 1980s and 1990s, in an effort to recruit Muslims to join the Jihad against the Soviet Union in Afghanistan and Chechnya, alQaeda produced propaganda videotapes showing the training of al-Mujahedeen and their heroic performance in real battles against the infidels of the former Soviet Union. These videos were usually accompanied by an audio track of Mujahedeen songs boasting superiority and Devine victory. Other than the propaganda nature of these long videos, there was no sophistication in their production values. These videos were mostly produced by handheld mini cameras using standard consumer lenses, mostly long shots and no sense of directing.

The development of ISIS from a terror group into a state with a developed social and economic system significantly advanced the media production capabilities of ISIS. This transformation is also attributed to advancement in the technology of cinema production, capital, and availability of production professionals sharing ISIS ideology. The feature of the beheading of American aid worker, Peter Kassig, released in November, 2014 had an estimated 
production equipment cost of $\$ 200,000$ (Stakelbeck, 2015, p. 7). Undoubtedly, ISIS has revolutionised the media production of Jihadist videos and transformed it to Hollywood film production standards.

\section{THE QUESTION OF THE AESTHETICS OF TERRORISM}

The mere placement of the word "aesthetics" next to "terrorism" is jarring and problematic, and opens up a rigorous debate on the feasibility of such combination. Exploring the aesthetics of terrorist visual production makes it even harder to promote into academic studies. In his work on the subject, Roberts $(2014$, p. 3) ascribed the difficulty of such task to "Kantian gold standard of modern aesthetic and moral thinking." For Kant, he added, "our experience of the sublime does not direct us toward aesthetic or imaginative contemplation of the scene of disaster or its natural causes but toward heightened moral feelings of sympathy and compassion for its victims" (Roberts, 2014, pp. 5-6). This is why "Damien Hirst's and Karlheinz Stockhousen's early calls for an aesthetic appreciation of 9/11 were met with harsh criticism and rebuke" (Battani and Manakel, 2017, p. 2). Roberts (2014, p.12) concluded in his discussion that "all productions of the will are aesthetic productions whether or not they give the impression of being mediated by artistic consciousness." Battani and Mankel's (2017) study contributed to the call for aesthetic appreciation and analysis of terrorist attacks by "building a Weberian ideal typology of terrorist aesthetics that includes but also goes beyond Arnold Berleant's important concept of the negative sublime" (Battani and Mankel, 2017 , p. 2). According to them "ideal types in the Weberian tradition are heuristic constructs that capture salient characteristics of social phenomena to create tools for comparative analysis" (2017, p. 2).

With the arrival of ISIS, not only the nature of terrorism evolved and changed, but also terrorist media production has changed thematically, ideologically and aesthetically. ISIS films in discussion are produced with artistic purpose on the part of the terrorist perpetration; they are predominantly artistic activities following the three phases of the film production process. The beheading films, the execution films of the Jordanian pilot, Mu'ath al-Kassabe and the Egyptian workers are models of well scripted, rehearsed and executed art productions that call for an aesthetic gaze unavailable to previous terrorist productions, intentional or unintentional. Therefore, the aesthetic definition of terrorism set forth by Battani and Mankel $(2017$, p. 4) as "a constellation of conventions for the production, distribution, and interpretation of violent events, images, text, and sound that terrify by design, where by design does not mean by intent" can be amended to include 'and by intent'.

\section{THE BEHEADING SOCIOGRAMS}

Undoubtedly, the Islamic State is highly secretive when it comes to its media operations (Winter, 2017, p. 118). There exists little information on the production process implemented by the propaganda arm of ISIS. The video entitled 'A message to America' first appeared on al-Hayat Media Center's account on the social networking platform Diaspora on 19 August 2014. The four minutes and forty seconds long video allegedly showed the beheading of the American photojournalist James Wright Foley at the hands of a masked black-clad ISIS insurgent where "the actual beheading is not explicitly shown in the video" (Friis, 2015, p. 725).

This video was subsequently followed by four beheading videos of American photojournalist Steven Sotloff (2 September 2014), British aid workers David Haines (13 September 2014) and Alan Henning (3 October 2014), and American aid worker Abdul-Rahman Kassig (16 November 2014), respectively (Friis, 2015, pp. 725-726). Despite attempted censorship, all five video were widely displayed on social media platforms, eliciting immediate international condemnation from government institutions, including the White House and Westminster, and generating what Hanna Kozlowska (2014) has termed "a modern guillotine execution spectacle, with YouTube as the town square." Julian Clarke, the chief executive of NewsCorps Australia, labelled the video as "the most horrendous thing that is going on in our world [a] brutal reality" (Kozlowska, 2014).

The five beheading videos distributed consecutively followed the same design where the victim appeared on screen wearing orange jump suite, kneeling on the ground next to a masked black-clad executioner holding bear hunting knife in hand addressing the viewers with a political message and threat aimed at a Western country and its leader, staged in a desert background open space in mid day. The actual beheading act in each film is not shown, rather the film moves forward in time to a shot of the decapitated head placed on the 
beheaded body of the victim. The closing scene resembles a sequel beheading of another victim shown dressed in orange kneeling next to the black dressed ISIS executioner.

These films display in their content and form a resistant voice against the power structure present in the discourse of "West" versus "East" and the Western hegemony targeting postcolonial states. The beheading films are sociograms heavily based on iconic representation in retaliation of Western superiority reflecting ISIS ideology or at least the ideology of what a future Islamic state might harbour. The use of body humiliation of captured victims juxtaposed with the body strength of the terrorist executioner is at the centre of this representation. The authoritative address in the form of a directed speech toward the "West" adds power to the narrative, outlining Western hegemonic oppression of Muslims since the collapse of the last Caliphate, and threatening with future attacks should political corrective demands are not met. In Foley's video, the executioner's address plays a role in asserting the legitimacy and statehood of ISIS through acceptance by Muslims and not UN charter. He says, "You are no longer fighting an insurgency-we are an Islamic army and a state that has been accepted by a large number of Muslims worldwide"

The use of visual "mimicry" is integrated into the narrative design of these films where several objects are mainly borrowed from Western ideology relevant to death and torture. The orange jump suit of the captured victims mimics the orange outfit of Jihadi captives held at Guantanamo Bay which represents the state of helplessness and humiliation of these captives. The black-clad represents the angel of death in Western ideology since the executioner is performing a divine justice. The knife used in the film is iconic of the slogan promoted in ISIS chants, "Ji'nakum bil-Dhabh" [We bring slaughter unto you].

The desert backgrounds in these films are iconographic representation of the sacred space, the cradle of Islam. According to Durkheim "the sacred status of sacred places is reproduced by forms of ritual, interpersonal and bodily behaviours that set the space apart and commemorate the founding myth (Smith, $1999,18)$. Yet, the desert in this case also takes the form of the profane space identified by Smith (1999, p. 21): "profane places are more often-but not always-the locus of subsequent, equally ritualistic attempts at destruction and obliteration."

Although these beheading films are minimalist in their cinematic language using mainly wide angle shots to show the whole scene, they are successful in creating an iconic representation of the "struggle" situation between forces of darkness - in ISIS's view: the United States and its allies - and the forces of the "Divine" ISIS and its divine penal code. Roelofs (2014, p. 177) argued that some of the aesthetic power of art is traceable to the way that works address their audiences, promising the creation of cultural community. These films promise the resurrection of the cultural affinity of the Islamic Caliphate prior to WWI. They address two kinds of audiences: the Western audience, and the Muslim audience. "Extremist content released onto the internet may not have the average Westerner in mind as an audience, but that extremist and terrorist networks online instead" (Hatton and Neilson, 2016, p. 166)

To Western audience, the construct of this culture is barbaric, bloody and terrorist. While to the Muslim audience who sympathise with ISIS's vision and ideology, this culture is justified and is a response to Western oppression and the corrupt monarchies installed by the West after WWI. ISIS claimed that "it had erased the old colonial boundaries established by the Western powers after World War I" (Hashim, 2014, p. 78). This claim was reinforced through videos displaying ISIS terrorists from across the Middle East tearing up their passports. In an empirical study on the causes of the Arab Spring, Byun and Hollander (2015, p. 41) found that corruption was the most important factor in mobilizing people against their corrupt governments. ISIS Media department was successful in using visual media to create strong iconographs rich in their politico-cultural value focusing on current political struggle between Islam as a nation and the Western powers.

\section{THE CINEMATIC GAZE: THE EXECUTION OF AL-KASSASBE}

When the film of the execution of Jordanian fighter pilot, Mu'ath al-Kassasbe, was released, it produced a shock and awe effect not only for its graphic content but also for its complex cinematic language "reminiscent of Hollywood blockbuster" (Malterre 2014). Using Hollywood visual repertoire, ISIS efficiently mixed "shocking images of atrocities with established visual tropes and narrative format, to inflict the affect of terror on viewers and 
shock their senses" (Kraidy 2017). Fleishman (2015) wrote:

\begin{abstract}
The videos released by Islamic State are slickly produced narratives of multiple camera angles, eerie tension and polished editing that suggest the filmmakers are versed in Hollywood aesthetics...The beheadings and other killings, including the burning alive of a captured Jordanian fighter pilot, represent an increasingly sophisticated cinema of terror.
\end{abstract}

Sienkiewicz (2018, pp. 122 - 123) stressed that "ISIS developed an increasingly emotional, narrative-driven, and bullying approach to new media." For Botz-Bornstein (2017, p. 6) "the approach of ISIS presents shocking elements able to provoke a violent response in the viewer similar to Futurism." The visual style used in al-Kassasbe film and several other similar films produced by ISIS can be described as emotional terror storytelling; a new genre developed by ISIS media department.

The film shows the story of the actual execution of al-Kassasbe by fire in a grandiose dramatic production. Using all elements of film production, the film was shot on location in several phases using four professional cameras. In the first phase, ISIS filmmakers executed a shot list of the scene without the presence of al-Kassasbe. In the second phase, they covered all the shots with alKassasbe on location. The duration that took to finish these two phases is unknown. The great details in the process of making this film indicate that the terrorists involved were in no rush to finish their production.

This twenty-two minute long film which was titled, Shifa' al-Sudor [The Healing of Chests], is the most sophisticated terrorist storytelling of our times. It appears as a public court administrated by ISIS presenting its case against al-Kassasbe reaching its sentencing, and ultimately executing him. The film, therefore, consists of two logical acts: the justification act, and the execution act.

In the justification act, the film shows alKassasbe in a variation of medium close-ups to close-ups confessing his crime and explaining in details the process through which he was ordered to bomb ISIS's location. In addition to confessing, al-Kassasbe shows great remorse for attacking his Muslim brothers incriminating the Jordanian government by accusing it of collaborating with the Western world against ISIS. An important question he delivers to the audience in a scripted manner is 'why Jordan would not direct its military power against Israel, the real enemy of the Muslims'. This rhetoric indicates to us that the primary target audience for this film is the Arab and Muslim audience since they primarily relate to this logic.

Scenes from al-Kassasbe's interviewconfession are intercut with visual narrative to support ISIS's logic in building the case against his barbaric atrocities. Examples of this visual narrative are: the actual night footage of the death toll and the destruction caused by al-Kassasbe's bombing, visual effects illustrating the rocket arsenal used in the raids and its damage capacities including burning of its targets, shots of civilian casualties from the raid focusing on a baby child receiving medical care, and finally futuristic quick cuts of al-Kassasbe in orange jumpsuit from the execution act.

Ironically, the discourse used in the first act is based on binary opposites where ISIS is portrayed as the victim and the United Statesled coalition as the villain. Giroux (2014, p. 4) noted that "echoing the discourse of the 'official' war on terrorism, the violence of extremist groups such as ISIS is produced almost exclusively within the vocabulary of moral absolutes pitting good against evil." This binary logic which according to Giroux (2014, p. 4) "devalues democratic, reasoned debate" mimics the United States stance 'you are either with us or with them' initiated by George W. Bush after 9/11. Using this logic, ISIS legitimises its revenge and brutal justice disregarding Islamic juridical rules of engagement in war and the rights of prisoners for safety and good treatment.

The justification act of the film relies heavily on digital technology mainly motion graphics in weaving the story and integrating the data together. It resembles, like earlier beheading films, the opening credits for Homeland TV series and warfare video games such as, Call of Duty. This implementation of modern technology lends ISIS aesthetics a sophisticated modern sense for the manipulation of time and space. BotzBornstein (2017, p. 9) observed that, "ISIS appropriates aesthetic codes from action movies and video games or it even appropriates entire games." This appropriation relates more closely to its target audience, the younger Muslim generations, and aims at involving them into these execution films. According to Eubin (2017, p. 1022) "digital interaction has the capacity to connect, involve, and implicate users-as participants, targets, sufferers, or warriors." In addition, the use of onboard camera footage from the 
fighter jet's missions, which is usually displayed on broadcast news showing the missiles targeting ISIS's locations, adds documentation and credibility to ISIS's argument as being the victim of the coalition's atrocities.

Throughout the justification act, carefully designed flame and fire custom transitions are used in editing to reinforce the atrocity and to add to the overall suspense theme of the film. This technique requires the use of motion graphics and plug-ins to create such transitions. These custom transitions also foretell the use of fire as the penal code for the execution of al-Kassasbe. Regardless of the level of skill and knowledge needed to create such effects in many of the motion graphics software available in the pro-consumer market, it is an indication to the filmmaker's attention to details in the weaving of the story.

In the execution act, the film shifts from the documentary genre to performance drama following a scripted narrative executed by a five- member crew using four professional cameras and a prepared shot list. The crew and equipment information was made available by the confessions of a captured ISIS terrorist (al-Arabiya, 2017).

The execution act opens up on al-Kassabe dressed in orange jump suit - entering the shooting set to wonder around amid the destruction caused by the raid. $\mathrm{He}$ is surrounded by ISIS terrorists who were distributed on location according to a scenario. Al-Kassasbe's performance shows remorse for his actions as he eyes the destruction he had caused while the terrorists stand firm in their blocked places on the set. The section relies heavily on camera movement and alKassasbe's movement. Camera shots and angles are designed to show the performance in great details following action continuity and point of view established by the four cameras. The narrative theme of this section is built on suspense using camera work and performance. Even al-Kassasbe himself was not aware of his end until the moment they drenched him with the flammable substance.

Shooting in open space is an aesthetic used in Hollywood action films. It gives the film an undisputed textural authenticity. The terroristperformers appear invincible on screen. The great number of the terrorist-performers and their distribution across the war ruins is a message in itself representing proliferation and persistence despite the coalition's attacks. The terrorist-performers clothed in new, clean, and pressed outfits embracing their weapons and their readiness for self-sacrifice capture the audiences' attention. "They seem as if regal sentinels in a perverted ideology to impose a primitive brand of Islamic law on what they see as a permissive and godless world" (Fleishman, 2015). Several close-ups textualise the narrative of their on-camera performance as the camera travels freely amidst their omnipresence without them looking straight into the camera. This convention, crucial to the plausibility of classical cinema, gives the audience the comfort of voyeuristic invisibility and mobility inviting them into the mise-en-scéne and granting them access to the spectacular space. This is an affective technique specifically for their recruiting campaign.

The uncanny atmosphere presented to the audience in this act is the result of a Durkheimian type of 'collective representation'. The scripted, rehearsed and staged performance of the subject-victim (alKassasbe), the performance of the executioners (directors, cinematographers, the terrorist-performers and extras on the set) and the cameras collide to produce this collective representation. The cameras, here, record a staged real propelling the bodies' status between reality and fiction. The film enlists a fictionalised reality to create a complex negotiation of real bodies, real worlds and personas in a fictionalised manner. AlKassasbe is, therefore, reduced to a real model performer in a pseudo fictionalised reality displaying the ideological state of ISIS's collective representation. His performance in this act, regardless of forcibility, is integrated with his confession of his crime, his remorse and his accusation of his government in the justification act. "Most films use elements of narrative cinema in the service of representation, as components that serve in the construction of an externalised and reassembled reality" (Goldsmith, 2019 p.2). ISIS aesthetics, hence, relies so much on bodies and their dynamic movement in addition to camera movement as narrative elements.

The scenes in the execution act progress to reach an unexpected spectacular ending - the torture and execution by fire of the model/performer -in an unprecedented display of realist horror. Thompson (2017, p. 51) argued that the strategy of ISIS's media parallels that of Nazi media strategy during WWII in its use of violence including "media modernity ... and a focus on engaging and recruiting young people." Despite such commonalities, this film takes modern violent 
propaganda into horrific levels beyond human comprehension. The detailed scene coverage of al-Kassasbe's burning in the cage using different camera angles and frames, shot for continuity is exceptionally ultra-violent and absolutely terrorising. Berleant (2009, p. 11) stressed that "such qualitative consequences as the human suffering from extreme acts of terrorism are beyond measure". The film offers a complete and permanent visual narrative account of the execution up until al-Kassasbe is reduced to a pile of ashes.

The enactment of this visual violence emphasises a visual rhetoric based on performative violence. According to Euben (2017, p. 1008) performative violence is the visual, symbolic, and communicative dimensions of political violence, an act of 'communication and dramatization' and an instrument of death. In a study Juris (2005) explored the complex relationship between performative violence and mass-mediated constructions of violence during the anti-G8 protests in Genoa. Juris (2005, p. 412) observed that "militant protest tactics involve the enactment of specific styles of violent performance through distinct bodily techniques, styles of dress, ritual symbols, and communicative practice." Based on Juris's discussion, I refer to 'performative violence', in this study, as a ritualised symbolic activity in order to produce concrete messages challenging global power, and generate radical identities to capture media attention. Applying this definition to the execution act of the film, it becomes clear that the whole act is a scripted political ritual built on performative violence enacted by all performers on the set.

However, the performative violence used in this film aims not only at establishing radical identity and challenging global power, but also at establishing state sovereignty. "Media representations have already become modes of military conduct" (Butler, 2009, p. 29). The use of torture in this film is a deliberate and scripted military conduct reinforcing ISIS's statehood claim. Khan (2009, p. 247) noted that "the sovereign power to take a life had to be witnessed in the double sense of seen and acknowledged". What we are witnessing with ISIS's execution films is the return to the scaffold as the locus for sacrifice for reasons of re-establishing the lost sovereignty of the Caliphate state in Islamic existence. This echoes the motto ISIS uses for branding its Caliphate: Khilafah 'ala minhaj al-nubowwa [A Caliphate according to the Prophet's model] where torture and death sentence is a mechanism solely in the hand of the Caliph.
The dramatisation of the execution is therefore an act of display of sovereign power in public since only the state possesses the sovereign power over life and death. Similar to Foucault's sovereign power - or the juridico-institutional power as he also calls it, the Caliphate has "the power of life and death" (Foucault, 1990, p.136). ISIS's sovereign power is derived from its interpretation of the sacred text found in Islamic jurisdiction (Shari'a) and therefore it is a divine power armed with Islamic law and with death as one of its penal codes. Khan (2009, p. 256) suggested that "when the terrorist kills proclaiming the greatness of his god, we are very close to witnessing again the spectacle of the scaffold." While this anachronistic practice terrorises Western audience it is viewed by ISIS supportive audience "as an expression of sovereign power" (Khan, 2009, p. 254).

The ending of the dramatic act with the violent visuals of al-Kassabe's torture to death leaves the audience in a state of shock and awe hard to overcome. The reason for that is due to the shift in our perception of violence from the scaffold to the battlefield. Botz-Bornstein (2017, p. 9) mentioned that, "ISIS cultivates in its videos a new "art of violence" for its shock value." As political violence texts, these films generated an overwhelmingly shock response throughout different venues. The shock value of this film is derived from the violent content and its cinematic sophistication. Robert Greenwald, president of Brave New Films, described the film as "horrific, but they know the power of storytelling and the importance of images" (Fleishman, 2015).

The cinematic language used in ISIS films is one that dramatises action with its main focus on the human "body". If for Bresson (1977), the performer is simply one component of cinema, for ISIS it is perhaps the central component. Execution in wars is not unusual, however, in making the victim's body the central theme, ISIS films use the body as the film's object transforming it into extraordinary, and thus the body "functions as a kind of message enforcement" (Chaplin, 2005, p. 6).

The centrality of the body in these films also foregrounds our relation to it through subjective embodiment and projection. Sinnerbrink (2016, p. 5) argued that "phenomenological approaches, foregrounding the experiential aspects of cinema, put the human subject back into the picture, albeit a subject defined by its affects, its corporeality, and its embodied difference." Audience response to the degradation, manipulation, and final sacrificial of the captured victims 
cannot but be characterised by emotional affect of empathy and sympathy for the victims, and with hatred and anger towards ISIS terrorists. A close analysis of these scenes shows that they manifest all elements and features used in fictional cinema scene design to elicit emotional response. These include, as observed by Sinnerbrink:

\begin{abstract}
$\ldots$ the use of close-ups and long takes focused on the facial expressions and bodily gestures of characters, that magnify the expression of affect and emotion but also ensure sufficient duration for an emotional dynamic to be established... stasis and movement, such as stasis of the camera to allow duration and expression to be perceived, and movement of the camera to express and generate kinetic resonance and affective excitation. (Sinnerbrink, 2016, p. 10)
\end{abstract}

Moreover, the use of the body in these films can be classified into two symbolic categories: the invincible and the subjugated. ISIS terrorists are always portrayed as fierce, invincible soldiers while their victims are portrayed subjugated and dominated. "Humiliation is elaborated ... through ... the visual inscription of impotence upon male bodies whose public subjugation and abjection is symbolically converted into that of the American nation" (Euben, 2017, p. 1010). This visual rhetoric as explained by Euben (2017, p. 1010) is an "enactment of retaliatory humiliation ... a symbolic transposition of status between the US and ISIS, enabling Da'ish to perform and publically display its invincible sovereignty." In doing so, ISIS "inscribed on the body of the victim the sacred presence of the sovereign" (Khan, 2009, p. 247).

\section{CONCLUSION}

ISIS revolutionised the media production of Jihadist videos and transformed it into a technically sophisticated film productions which surpassed its predecessors in an unprecedented quality both thematically and aesthetically. ISIS heavily relied on aesthetic and thematic appropriation of film production, reminiscent of Hollywood blockbusters. Using visual media, ISIS created sociograms heavily based on iconic representation in retaliation of Western superiority. ISIS used performative violence as a visual style in developing an emotional terror storytelling genre. The emotional terror in ISIS films shocked and terrorized its target audience in an unparalleled way emphasising its Islamic
Caliphate claim and challenging global power. These films reflect a level of thematic and aesthetic sophistication only available to specialized personnel steeped in filmmaking. Future discoveries might unravel the identity and background of the makers of these films.

\section{REFERENCES}

Al-Arabiyya TV Special Report. (2017). Interview with Abu Mus'ab al-Urduni. AlArabiya TV. Available at: https://www.alarabiya.net/ar/arab -andworld/2017/02/11. (Accessed: 5 Apr. 2019).

Battani, M. and Mankel, M. (2017) 'Terrorist Aesthetics as Ideal Types: from Spectacle to 'Vicious Lottery'. Contemporary Aesthetics, 15(1).

Berleant, A. (2009) 'Art, Terrorism and the Negative Sublime'. Contemporary Aesthetics, 7, pp.1-14.

Botz-Bornstein, T. (2017) 'The "futurist" aesthetics of ISIS'. Journal of Aesthetics \& Culture, 9(1), pp. 1 - 13.

Bresson, R. (1977) Notes on cinematography, United States.

Butler, Judith. (2009) Frames of War: When Is Life Grievable? London: Verso.

Byun, C. C. and Hollander, E. J. (2015) 'Explaining the Intensity of the Arab Spring'. Digest of Middle East Studies, 24(1), pp. 26-46.

Chaplin, A. (2005) 'Art and Embodiment: Biological and Phenomenological Contributions to Understanding Beauty and the Aesthetic'. Contemporary Aesthetics, 3, pp. 1-21.

Eubin, R. (2017) 'Spectacles of Sovereignty in Digital Time: ISIS Executions, Visual Rhetoric and Sovereign Power'. Perspectives on Politics, 15(4), pp. 10071033.

Fleishman, J. (2015) 'Islamic State and its increasingly sophisticated cinema of terror', Los Angeles Times, 26 February. Available at:

https://www.latimes.com/entertainment/movi es/la-et-mn-ca-isis-video-horror-20150301story.html (Accessed 19 May 2019).

Foucault, M. (1990) The history of sexuality: An introduction, volume I. Translated by $\mathrm{R}$. Hurley. New York: Vintage.

Friis, S. M. (2015) 'Beyond anything we have ever seen: beheading videos and the 
visibility of violence in the war against ISIS'. International Affairs, 91(4), pp. 725-746.

Giroux, H. (2014) 'ISIS and the spectacle of terrorism: Resisting mainstream workstations of fear'. Philosophers for Change. Available at: https://philosophersforchange.org/2014/10/ 07 (Accessed: 19 May 2019).

Goldsmith, L. (2019) 'The Body is a Fact', Senses of Cinema, 90. Available at: http://sensesofcinema.com/2019/valeriemassadian/the-body-is-a-fact (Accessed: 15 May 2019).

Hashim, A. S. (2014) 'The Islamic State: From al-Qaeda Affiliate to Caliphate'. Middle East Policy, XXI(4), pp. 69-83.

Hatton, Arthur. T. and Nielsen, M. E. (2016) 'War on Terror' in our backyard: effects of framing and violent ISIS propaganda on anti-Muslim prejudice'. Behavioral Sciences of Terrorism and Political Aggression, 8(3), pp. 163-176.

Juris, J. (2005) 'Violence Performed and Imagined'. Critique of Anthropology, 25(4), pp. 413-432.

Khan, P. W. (2009) 'Torture and Democratic Violence'. Ratio Juris, 22(2), pp. 244-259.

Kozlowska, H. (2014) 'Should we be seeing gruesome acts and if so where?', New York Times, 25 August. Available at: http://optalk.blogs.nytimes.com/2014/08/25 (Accessed: 15 May 2019).

Kraidy, M. (2017) 'This is why the Islamic State shocks the world with its graphically violent imagery', The Washington Post, 9 February. Available at: https://www.washingtonpost.com /news/ monkey-cage/wp/2017/05/19/ (Accessed: 19 May 2019).
Malterre, S. (2014) 'ISIS jihadists put out Hollywood-style propaganda film', Observers.france24.com, 13 June. Available at: https://observers.france24.com/en/201406 13 (Accessed: 19 May 2019).

Roberts, J. (2014) 'Rethinking the Sublime: Is There an Aesthetics of Terrorism?'. Note by György Fogarasi, Americana: E-Journal of American Studies in Hungary, 10(1). Available at: http://americanaejournal.hu/vol 10no1/roberts (Accessed: 15 May 2019).

Roelofs, M. (2014) The Cultural Promise of the Aesthetic. London: Bloomsbury.

Sienkiewicz, M. (2018) 'Arguing with ISIS: web 2.0, open source journalism, and narrative disruption'. Critical Studies in Media Communication, 35(1), pp. 122-135.

Sinnerbrink, R. (2016) 'Cinempathy: Phenomenology, Cognitivism, and Moving Images'. Contemporary Aesthetics, 8, pp.114.

Smith, P. (1999) 'The Elementary Forms of Place and Their Transformations: A Durkheimian Model'. Qualitative Sociology, 22(1), pp. 13-36.

Stakelbeck, E. (2015) ISIS Exposed: Beheadings, Slavery, and the Hellish Reality of Radical Islam. Washington, DC: Regency Publishing.

Thompson, G. (2017) 'Parallels in propaganda? A comparative historical analysis of Islamic State and the Nazi Party'. Journal of Public Relations Research, 29(1), pp. 51-66.

Winter, C. (2017) Apocalypse, later: a longitudinal study of the Islamic State brand'. Critical Studies in Media Communication, 35(1), pp. 103-121. 